\title{
Evaluation of using crushed brick as coarse aggregate in concrete layer within rigid highway pavement
}

\author{
Ali Alwash ${ }^{1}$, Fatimah Al-Khafaji $^{1}$ \\ ${ }^{1}$ University of Babylon, Babylon, Iraq \\ ${ }^{2}$ University of Babylon, Babylon, Iraq
}

\begin{abstract}
Most of the present studies related to the field of highway pavement construction technique tend to make use of the local available materials as substitutes for the imported and necessary materials for some of the practical application. For this reason this research aims at looking for the prospect of used locally available aggregate such as crushed clay bricks for the aim of producing proper concrete with suitable thermal and mechanical properties. Experimental investigations have been carried out to asses the effect of partial replacement of coarse aggregate by free manually crushed Brick with percentages $(10,20,30$ and 40$) \%$ of virgin coarse aggregate in concrete mix for highway rigid pavement. While the percentage $(0) \%$ replacement represent reference mix. Mix proportion based on the target of compressive strength for all replacement percentage of (33) $\mathrm{MPa}$ at (28) days to achieve AASHTO requirement for highway concrete rigid pavement .The results of flexural strength, modulus of elasticity, density and thermal conductivity refers to better performance (less thickness of concrete layer with large spacing between contraction or expansion joints and less stresses due to warping induced concrete layer) for concrete mix with $20 \%$ crushed brick as replacement of coarse aggregate.
\end{abstract}

\section{Introduction}

Concrete is the widely used paving material due to suitable features such as durability, strength, cast effectives and availability.

The clay brick from demolished construction wall. [1]

From the last years, it has been established as the growing problem of the waste from the demolished construction walls which exist in every location of the world. The sustainable use of this waste can solve large environmental problems.

Accumulation of these waste is considered as real problem. Therefore these demolished construction waste should be recycled and reused as raw materials for new application like rigid pavements recycled crushed brick can be used for manufacturing concrete mix with suitable features for ensure sustainable management for this operation. [2]

Recycling materials is defined as reusing of old ones in new application. By this operation, the consumption of raw materials is reduced and the waste is eliminated.

Recycled crushed brick as fine aggregate can be used for producing mortar as well as concrete mix.

The use of this waste materials have good effect on economy. Some application needs utilization of low cost materials without any bad impact on the environment.

Almost, at the preparation of concrete mix, the aggregate is used more than cement because it's the cheapest and the strength of aggregate is very significant for the final concrete strength. Therefore the percentage of aggregate equal to $70-80 \%$ of the total volume of concrete mix. [2] The use of crushed brick aggregate must be under investigation for important application. A review on the subject indicated that there was another information of the utilization of such waste however the crushed brick aggregate is different from that of crushed concrete aggregate due to its porosity. [3]

Some researchers used good burnt crushed brick as coarse aggregate in concrete for achieving high strength concrete. This was done by finding mechanical properties of brick aggregate concrete without needing that of crushed brick aggregate itself.

Other researchers used clinker brick after crushing as coarse aggregate. It was found only $7 \%$ loss in compressive strength of concrete in comparison to that with natural aggregate. But there is a decrease in density of crushed brick concrete by about $9.5 \%$. [3]

Recycled crushed brick aggregate has an absorption values $22-25 \%$ by weight in comparison with dry material. For the study of this property, it obtained that the saturation time in water is $30 \mathrm{~min}$ and the absorption of waste aggregate concrete is higher by about $20 \%$ than that of control cement with variation according the type and composition of waste aggregate. But the use of 
crushed brick aggregate with fine gradation leading to higher cement content in concrete mix. [1,2]

Therefore the major problem of using crushed brick after recycling as aggregate its high water absorption. [4]

\section{Experimental works}

\subsection{Materials}

\subsubsection{Cement:}

Sulfate resistance cement was used. The specific gravity of the cement used was 3.15.

2.1.2. Fine aggregate:

Normal weight natural sand from Kerbala region was used as fine aggregate. The grading of the requirement of Iraqi specification No.45/1984, grading area (3).

\subsubsection{Coarse aggregate}

\section{Natural gravel}

The grading was within the limits of gravel by British Standard (B.S..882:1973)

\section{Crushed brick:}

Free manually crushed brick (as demolished building material). The grading is made in a manner similar to grading of natural gravel aggregate.

\subsubsection{Concrete Mix:}

The concrete mix and water-cement ratio based on target C 30 an portable water was used in all mixes.

\subsubsection{Curing}

After casting, the specimens were separated and kept in the water bath for a curing period of 28 days for proper hydration process under laboratory temperature.

\subsection{Tests:}

- The compressive strength is fabricated according to B.S: (1881, part 116, 1989).

- The modulus of rupture and static modulus of elasticity are performed according to (ASTM C78-2002) and (ASTM C469-2002) respectively.

- The linear coefficient of thermal expansion is calculated according to AASHTO TP60-2004 while thermal conductivity as a measure of the rate at which heat passes through unit thickness for a temperature difference of one degree, is measured according to (ACI 122R-02)

\section{Results and Discussion}

\subsection{Dry density}

Table (1) shows the densities for all specimens. It is noticed that the density decreases by replacing natural gravel by crushed brick. Also this light weight aggregate (LWA) presents a reduction in density from normal weight concrete ranging between $9 \%$ to $20 \%$.

\subsection{Compressive Strength:}

The results reported are the average of 3 specimens as shown in Table (2) at the age of 28 days. There is a reduction in strength that may belong to two causes:[5]

- Recycled brick have no proper bond with cement in concrete mix.

- High porosity of crushed brick surface leading to higher water requirement for workability.

Increasing the substation content with waste aggregate leading to decrease in 28 days compressive strength with range of $5-11 \%$ when compared with control concrete. This variation in decrease depends on the strength of original brick. Therefore we can estimate the strength of recycled aggregate concrete from the strength of original brick. $[2,6]$.

However, the strength of wasted concrete agree with requirement of pavement applications in highway (above $30 \mathrm{MPa})$.

\subsection{Flexural Strength:}

Flexural strength is defined as the stress breaking or deforming permanently and the material and the result as shown in Table (2). The angularity of the crushed brick aggregate and its surface roughness leading to proper bond between aggregate and the cement paste that could increase the flexural strength as shown for $20 \%$ replacement that aggregate with [2,7]. Although of that mentioned above, flexural strength of crushed brick concrete is about $15 \%$ lower than that of control concrete.

\subsection{Modulus of Elasticity:}

Elastic modulus of concrete is related to the elastic modulus of the aggregate and the cement paste and their relative parentage. The modulus of elasticity of concrete with crushed brick as an aggregate is about 12-23\% lower than the one of a normal concrete as shown in Table (2). With the increase percentage of substitution of natural aggregate with crushed brick aggregate, the modulus of elasticity decreases which agreed with [2].

\subsection{Thermal Conductivity and Coefficient of Thermal expansion:}

Thermal conductivity is the character of material that shows its possibility for heat conductivity. The thermal 
behavior of concrete is indicated by means of the thermal conductivity. The results of test are shown in Table (3).

Thermal conductivity is also defined as the quality of heat gradient per unit time between entering face and leaving at the opposite face at a temperature difference of about one degree.

Usually the mineralogical property of aggregate, water with air voids content and temperature with moisture state of concrete, affect significantly on the thermal conductivity of control concrete. Therefore thermal conductivity decreases significantly by variance of moisture content in the concrete state. While the source of aggregate significantly influences the thermal conductivity of concrete.

Almost, small length change due to expansion and contraction of materials related to the rising or falling temperature. Therefore the coefficient of thermal expression is the best measure of them. This coefficient is the main parameter to be adopted in the rigid pavement design. The average value of the coefficient is already used for pavement design. The variance in type of aggregate used in the concrete mix causes numerous values of coefficients. But this operation leads to a wrong assumption of thermal movement and any possible distress.

The coefficient of thermal expansion of recycled crushed brick concrete, is lower than that of control concrete that agreed with $[\mathbf{2 , 8}]$. This decrease is due to low coefficient of thermal expansion of waste materials. The result is shown in Table (3).

Table 1. Results of density for different concrete mix (different percentage of coarse aggregate replacement by crushed brisk) at age 28 days.

\begin{tabular}{|l|l|l|l|l|l|}
\hline Mix type & $\begin{array}{l}\text { (0\% } \\
\text { rep.) }\end{array}$ & $\begin{array}{l}\text { (10\% } \\
\text { rep.) }\end{array}$ & $\begin{array}{l}\mathbf{( 2 0 \%} \\
\text { rep.) }\end{array}$ & $\begin{array}{l}\mathbf{( 3 0 \%} \\
\text { rep.) }\end{array}$ & $\begin{array}{l}\text { (40\% } \\
\text { rep.) }\end{array}$ \\
\hline $\begin{array}{l}\text { Density } \\
\mathrm{kg} / \mathrm{m} 3\end{array}$ & 2324 & 2115 & 2040 & 1899 & 1870 \\
\hline
\end{tabular}

Table 2. Results of compressive strength, modulus of rupture and modulus of elasticity for different concrete mixes (different percentages of coarse aggregate replacement by crushed brick) at age 28 days.

\begin{tabular}{|l|l|l|l|}
\hline Mix type & $\begin{array}{c}\text { Compressive } \\
\text { strength } \\
\text { (MPa) }\end{array}$ & $\begin{array}{c}\text { Modulus } \\
\text { of } \\
\text { rupture } \\
\text { (MPa) }\end{array}$ & $\begin{array}{c}\text { Modulus } \\
\text { of } \\
\text { elasticity } \\
\text { (GPa) }\end{array}$ \\
\hline $\begin{array}{l}\text { Reference } \\
\text { mix } \\
(0 \% \\
\text { replacement) }\end{array}$ & 36.80 & 5.60 & 29.6 \\
\hline $\begin{array}{l}(10 \% \\
\text { replacement })\end{array}$ & 34.71 & 4.75 & 26.0 \\
\hline $\begin{array}{l}(20 \% \\
\text { replacement) }\end{array}$ & 33.90 & 5.35 & 25.5 \\
\hline $\begin{array}{l}(30 \% \\
\text { replacement })\end{array}$ & 33.20 & 4.91 & 24.1 \\
\hline $\begin{array}{l}(40 \% \\
\text { replacement })\end{array}$ & 33.04 & 4.70 & 22.8 \\
\hline
\end{tabular}

Table 3. Results of thermal conductivity, coefficient of thermal expansion for different concrete mixes (different percentage of coarse aggregate replacement by crushed brick) at age 28 days.

\begin{tabular}{|l|l|l|}
\hline Mix type & $\begin{array}{l}\text { Thermal } \\
\text { conductivity } \\
\text { W/m Kelvin }\end{array}$ & $\begin{array}{l}\text { Coefficient } \times \\
\mathbf{1 0 - 6} \text { expansion } \\
\mathbf{m m} / \mathbf{m m} / \mathbf{C o}\end{array}$ \\
\hline $\begin{array}{l}\text { Reference mix } \\
(0 \% \text { replacement })\end{array}$ & 2.19 & 13.87 \\
\hline $\begin{array}{l}(10 \% \\
\text { replacement })\end{array}$ & 1.51 & 13.19 \\
\hline $\begin{array}{l}(20 \% \\
\text { replacement })\end{array}$ & 1.35 & 13.03 \\
\hline $\begin{array}{l}(30 \% \\
\text { replacement })\end{array}$ & 1.28 & 12.69 \\
\hline $\begin{array}{l}(40 \% \\
\text { replacement })\end{array}$ & 1.27 & 12.95 \\
\hline
\end{tabular}

\section{Design thickness of concrete layers:}

Rigid highway pavement is concrete layer with thickness (h) on base (or subbase) layer. The strength is needed for the beam action of the layer due to the high modulus of elasticity of concrete. Thickness nomograph has a wide range in values of flexural strength and modulus of elasticity [9]. Table (4) shows a comparison which is based on layer thickness and different concrete mixtures.

Table 4. Calculated thickness values of concrete slab for various concrete mixtures types.

\begin{tabular}{|l|l|l|l|l|l|}
\hline Mix type & $\begin{array}{l}\mathbf{W}_{\mathbf{1 8}^{*}} \\
\mathbf{1 0}^{\mathbf{3}}\end{array}$ & $\begin{array}{l}\mathbf{K} \\
\text { (pci) }\end{array}$ & $\begin{array}{l}\text { MR } \\
\text { (psi) }\end{array}$ & $\begin{array}{l}\mathbf{E}^{*} \mathbf{1 0}^{\wedge} \\
\left.\mathbf{6}^{\wedge} \mathbf{p s i}\right)\end{array}$ & $\begin{array}{l}\mathbf{H} \\
\text { (in) }\end{array}$ \\
\hline $\begin{array}{l}\text { Reference } \\
\text { mix (0 } \\
\text { replacement) }\end{array}$ & 4000 & 200 & 812 & 4.29 & 7.9 \\
\hline $\begin{array}{l}(10 \\
\text { replacement) }\end{array}$ & 4000 & 200 & 688 & 3.77 & 8.4 \\
\hline $\begin{array}{l}\text { (20 } \\
\text { replacement) }\end{array}$ & 4000 & 200 & 776 & 3.71 & 8.0 \\
\hline $\begin{array}{l}(30 \\
\text { replacement) }\end{array}$ & 4000 & 200 & 712 & 3.49 & 8.3 \\
\hline $\begin{array}{l}\text { (40 } \\
\text { replacement) }\end{array}$ & 4000 & 200 & 682 & 3.30 & 8.7 \\
\hline
\end{tabular}

Where:

$\mathrm{W}_{18}$ : Predicted number of $18 \mathrm{Kip}$ equivalent single axle load application.

MR: modulus of rupture (psi).

$\mathrm{K}$ : modulus of subgrade reaction (pci)

E: modulus of elasticity for Portland cement concrete (psi)

The thickness design results indicate that the concrete mixtures containing $20 \%$ coarse aggregate replacement by crushed brick render the slab concrete thickness of rigid more slightly using reference concrete mixtures . 


\section{Stresses due to warping}

Usually, if the concrete layer is subjected to temperature grading with depth, layer surface is warping (which means concave the layer edges down during day and concave up during the night). But the effect of temperature grading is resisted by the weight of layer which will hold the layer in its first state.

Table (5) illustrates the edge and interior stresses due to warping of concrete slab for various concrete mixtures type adopted in this research in case of using these mixes in construction of rigid pavement highway.[10]

a: $\sigma_{i x}=(E * \alpha * \Delta T * 0.5) *\left\{\left(C_{x}+\mu C_{y} /\left(1-\mu^{2}\right)\right\}\right.$

as $\sigma_{i x}$ : internal stress in $\mathrm{x}$ direction due to warping

b: $\sigma_{e x}=\left(C_{x} * E * \alpha * \Delta T\right) / 2$

as $\sigma_{e x}$ : edge stress in x direction due to warping. as $\mathrm{I}=\left\{\left(E * h^{3}\right) /\left(12 k *\left(1-\mu^{2}\right)\right\}^{\wedge 1 / 4}\right.$

where:

Radius of relative stiffness (inch)

Pavement layer thickness (from Table 4)

Poisson's ratio of the pavement taken 0.15 for concrete

Linear coefficient of thermal expansion $\left(\mathrm{mm} / \mathrm{mm} /{ }^{\circ} \mathrm{F}\right)$ (From Table 3)

From Bradbury curve, $\left(\right.$ as $\left.\mathrm{L}_{\mathrm{x}} / \mathrm{I} \& \mathrm{~L}_{\mathrm{y}} / \mathrm{I}\right)$

Table 5. Calculated stresses due to warping of concrete slab for various concrete mixture types

\begin{tabular}{|l|l|l|}
\hline \multirow{2}{*}{ concrete type } & \multicolumn{2}{|l|}{ Stress due to warping psi } \\
\cline { 2 - 3 } & Interior & Edge \\
\hline $0 \%$ & 440.7 & 391.0 \\
\hline $10 \%$ & 393.1 & 360.7 \\
\hline $20 \%$ & 382.8 & 351.8 \\
\hline $30 \%$ & 370.7 & 337.3 \\
\hline $40 \%$ & 365.2 & 335.0 \\
\hline
\end{tabular}

For interior warping stresses, the results indicate that coarse aggregate with $20 \%$ replacement by crushed brick gives a decrease in warping stresses by (13\%) compared to reference concrete mixtures for the two joint distance and for edge warping stresses to the results indicate that coarse aggregate with $20 \%$ replacement by crushed brick give a decrease in warping stresses by (10\%) compared to reference concrete mixtures for the two joint distances. This behavior is due to the low coefficient of thermal expansion and thermal conductivity of coarse aggregate with $20 \%$ replacement by crushed brick reference mix.

\section{Conclusions}

After reviewing of main properties of concrete made with crushed clay brick as an aggregate and according to results of experimental investigation that are shown in the research, following facts are concluded:

- Compressive strength decreases slightly when using clay brick as coarse aggregate with up to $40 \%$ replacement and achieving the pavement requirements.

- Modulus of rapture decrease when using clay brick as coarse aggregate but this decrease became very less at $20 \%$ replacement.

- The values of modulus of elasticity with modulus of rapture at $20 \%$ coarse aggregate replacement by clay brick, reflected on concrete layer thickness same to that of reference mix (lower very slightly)

- Density decreases significantly when using clay brick as coarse aggregate for all replacement percentage and this decrease imposed a clear increase in joint spacing.

- The use of clay brick as coarse aggregate improve the thermal insulation properties of concrete layer, for all replacement percentage.

- It seems that, the use of clay brick waste which has a very high absorption of water is a very effective technique for sustaining cement hydration and increases the volume of hydration products that fill pores within the concrete and increase its durability.

\section{References}

1- J. Yang, D. Qiang, B. Yiwang, Construction and Building Materials 25: 1935-1945 (2011).

2- K. Ivana, N. Ivanka, \& B. Dubravka, Technical Gazette, 15 (3), 35-40 (2008).

3- M. G. Osama. 17 (4): 1022-1038 (2011).

4- S. R. Laith \& M. R. M. Laith. 2 (5): 45-52( 2013)

5- M. S. Haifa, Tikrit Journal of Engineering Sciences. 19 (3): 33-40 (2012)

6- M. A. Haider, Journal of Babylon University, Pure and Applied Sciences 19 (1): 226-239 (2011)

7- K. M. Hamoud "Effect of addition of steal fibers on compressive and tensile strength of structural light weight concrete made of broken bricks". IJCE-7 ${ }^{\text {th }}$ issue. 99-118. (2007)

8- A. Shakir and E. Maha, Eng and Tech. 26 (12):1508-1513 (2008)

9- AASHTO Guide for design of pavement structures. (1993)

10- V. Tom Mathew and K. V. Krishna Rao." Introduction to Transportation Engineering". NPTEL. 16: 1-6. (2007). 